year after first primary; he had a second primary in the other testis four years after marriage.

36-40 Years (9 Patients). - Two had three children conceived and born after treatment, one of whom already had three children; seven had 12 children before onset of tumour, three of whom were known to have then limited their family by choice.

41-45 Years (6 Patients).-One had a child after treatment, none before. Four were fathers before onset of tumour, having nine children. One known to have then limited the family by choice; one adopted a child after treatment, having no family before onset of tumour.

46 Years and Over (16 Patients).-Fourteen were fathers of 26 children before onset of tumour; one was fertile before treatment (miscarriage) and then a prisoner of war for five years and had a wife much older than himself; one was fertile before treatment (wife had a miscarriage followed by hysterectomy).

The time of conception ranged from during treatment in one patient and five months after treatment in another (despite the warnings given) to 12 years after treatment. Most of these patients conceived their children within a two-to three-year interval after the irradiation but there was a gap before the first child was born of four, five, six, eight, 11 , and 12 years in other cases. All these children appear normal. Twenty-seven were born to patients who had had seminomas and 25 to those who had had teratomas.
The risks of transmitting radiation-induced chromosomal abnormalities may be high in the immediate postradiation period if damaged spermatozoa are still viable, but a period of sterility or subfertility lasting a few months to a few years may follow the irradiation. We tell patients who have been irradiated for testis tumours that they should avoid parenthood during or directly after treatment and advise them to wait for at least a year.

We are grateful to Miss Margot Hannam, superintendent radiographer, for keeping the records of children for our Testicular Tumour Unit.

\section{References}

Amelar, R. D., Dubin, L., and Hotchkiss, R. S. (1971). Fournal of Urology, 106, 714 .

Kom, C.., Mulholland, S. G., and Edson, M. (1971). Fournal of Urology, $105,528$.

Orecklin, J. R., Kaufman, J. J., and Thompson, R. W. (1973). Fournal of Urology, 109, 293.

Smithers, D. W., and Wallace, E. N. K. (1962). British Fournal of Urology, 34,422 .

Smithers, D. W., Wallace, E. N. K., and Wallace, D. M. (1971). British fournal of Urology, 43, 83.

Smithers, D. W. (1972). Fournal of the Royal College of Surgeons of Edinburgh, 17, 133 .

Walsh, P. C., Kaufman, J. J., Coulson, W. F., and Goodwin, W. E. (1971) Fournal of the American Medical Association, 217, 309.

Whitmore, W. F., jun. (1970). Sixth National Cancer Conference Proceedings, p. 219. Philadelphia, Lippincott.

\title{
Vagotomy or Gastrectomy for Gastric Ulcer
}

\author{
H. L. DUTHIE， N. K. KWONG
}

British Medical fournal, 1973, 4, 79-81

\section{Summary}

Patients treated in a randomized controlled comparison of management of benign gastric ulcer of the body of the stomach, comprising 50 patients treated by Billroth I partial gastrectomy and 50 patients treated by vagotomy and pyloroplasty and biopsy of the ulcer, were followed up for about five years (range one and a half to eight and a half years). No statistically significant difference has been found between the functional results (Visick grading) of the two groups. There was no operative mortality. Postoperative morbidity (17 against 5 ) and length of stay in hospital (14 against 10 days) were significantly greater after gastrectomy. Seven patients after vagotomy have been submitted to gastrectomy (three for recurrent gastric ulceration, three for gastric cancer, and one for bleeding), which is a statistically significant excess compared with no reoperation after gastrectomy. While vagotomy and pyloroplasty can be useful to avoid a technically difficult gastrectomy, it cannot be said to replace partial gastrectomy in the treatment of gastric ulcer.

\section{Introduction}

In keeping with the general trend towards conservative surgery for peptic ulceration, we have been comparing vagotomy and

\footnotetext{
University Department of Surgery, The Royal Infirmary, Sheffield S6 3DA

H. L. DUTHIE, M.D., CH.M., Professor of Surgery

N. K. KWONG, M.D., F.R.C.S., Research Assistant
}

pyloroplasty with Billroth I gastrectomy in the surgical treatment of gastric ulceration. Initial results have been reported (Duthie et al., 1970). We now present longer-term follow-up which shows that the initial superiority of gastrectomy has not been maintained with the passage of time.

\section{Methods}

From 1964 to 1971100 consecutive cases of peptic ulceration of the body of the stomach, excluding emergency operations, have been included in a randomized controlled trial of the operation of vagotomy and pyloroplasty compared with Billroth I gastrectomy. The patient was entered into the trial when the diagnosis was confirmed at operation and no evidence of duodenal ulceration or of an ulcer within $2 \mathrm{~cm}$ of the pylorus was found. A biopsy of the ulcer was performed. Initially a four-quadrant biopsy specimen was taken but in the last 25 cases a circumferential specimen of the whole ulcer was obtained and sent for immediate histological examination. During this period seven cases (three selected for vagotomy, and four selected for gastrectomy) were found to have an ulcer/cancer and 100 cases had benign ulceration. The cases with ulcer/cancer are considered separately. Standard operative techniques were used. Truncal vagotomy was used in 41 cases and selective vagotomy in nine cases, each combined with a Heineke-Mikulicz pyloroplasty. About $50-60 \%$ of the stomach was removed at gastrectomy. The gastric remnant was anastomosed to the duodenum (Billroth I). Insulin tests were performed on patients with postoperative symptoms.

At follow-up patients were interviewed personally and particular note was made of any postoperative symptoms. Direct questions were asked concerning presence of diarrhoea, dumping, bilious vomiting, distension, and any dyspepsia. After full examination the patients were weighed, their height was meas- 
ured, and blood samples were taken for estimation of the levels of haemoglobin, iron, vitamin $B_{12}$, and folate. The nature of the operation performed was not known to the interviewer at the time of assessment. The overall functional results were graded by a modification of the Visick classification as follows: grade 1no gastric symptoms; grade 2-moderate symptoms easily controlled by simple care such as avoidance of certain foods, taking of smaller meals, and short periods of rest after meals; grade 3-moderate symptoms not controlled by simple measures but not interfering with the patient's social or economic life; and grade 4-More severe symptoms interfering with social or economic life or definite recurrence of symptoms which were as bad as or worse than before operation.

\section{Results}

Of 100 cases with benign gastric ulcer of the body of the stomach two groups of 50 were treated by the two operations. They were comparable with regards to sex distribution, age, length of the history of symptoms, and length of follow-up (table I).

TABLE I-Various Data Relating to Both Groups of Patients

\begin{tabular}{|c|c|c|}
\hline & Gastrectomy & Vagotomy \\
\hline 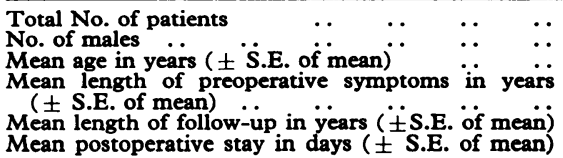 & \begin{tabular}{|c|}
50 \\
33 \\
$54 \cdot 1$ \\
$\pm 1 \cdot 3$ \\
$7 \cdot 2 \pm 0.9$ \\
$5 \cdot 1 \pm 0.3$ \\
$13.9 \pm 1 \cdot 4^{*}$
\end{tabular} & $\begin{aligned} & 50 \\
& 32 \\
& 50 \cdot 3 \pm 1 \cdot 4 \\
& 7 \cdot 3 \pm 1 \cdot 0 \\
& 4 \cdot 5 \pm 0 \cdot 4 \\
& 10 \cdot 3 \pm 0 \cdot 3^{*}\end{aligned}$ \\
\hline
\end{tabular}

*Significant difference, $t=2.44 ; \mathrm{P}<0.02$.

The patients were interviewed personally in 46 out of 50 cases after gastrectomy and in 40 out of 50 after vagotomy. Details from previous interviews were used for three patients after gastrectomy who had died of unrelated causes (coronary thrombosis, cerebral thrombosis, hepatic necrosis) and for two patients after vagotomy (meningitis, coronary thrombosis). Three patients initially treated by vagotomy later died of gastric carcinoma and together with another four patients in this group who were submitted to gastrectomy (table IV) were graded as Visick 4. One patient could not be traced and records of the 1970 follow-up were used. The last patient (having moved out of the district) was interviewed by telephone. Postoperative morbidity was greater after gastrectomy and the difference reached statistical significance (table II). As a result the mean length of stay in hospital after gastrectomy was significantly greater than after vagotomy and pyloroplasty-13.9 days as against 10.3 days (table I). No longterm effects resulting from this greater morbidity were encountered.

TABLE II-Details of Postoperative Morbidity

\begin{tabular}{|c|c|c|c|c|c|}
\hline & & & & \multicolumn{2}{|c|}{ Postoperative Morbidity } \\
\hline & & & & Vagotomy & Gastrectomy \\
\hline $\begin{array}{l}\text { Haemorrhage } \\
\text { Leakage at suture line } \\
\text { Paralytic ileus } \\
\text { Hold-up at stoma } \\
\text { Wound rupture } \\
\text { Pulmonary embolism }\end{array}$ & $\begin{array}{l}\ldots \\
\cdots \\
\cdots \\
\cdots \\
\cdots\end{array}$ & $\begin{array}{l}\ldots \\
\cdots \\
\cdots \\
\cdots\end{array}$ & $\begin{array}{l}\ldots \\
\because \\
\cdots \\
\cdots\end{array}$ & $\begin{array}{l}2 \\
1 \\
1 \\
0 \\
0 \\
1\end{array}$ & $\begin{array}{l}2 \\
3 \\
3 \\
3 \\
3 \\
3\end{array}$ \\
\hline Total & . & $\cdots$ & . & $5^{*}$ & $17^{*}$ \\
\hline
\end{tabular}

*Significant difference, $\chi^{2}=8.39 ; P<0.01$.

\section{FUNCTIONAL RESULTS}

The overall functional results graded on the Visick classification (table III) show no significant difference between the two operations though there are a greater number of poor results after vagotomy (table IV). Statistically significantly more patients
TABLE III-Functional Results Graded on Visick Classification

\begin{tabular}{|c|c|c|c|c|c|c|c|c|c|c|c|c|c|}
\hline & & & & & & \multicolumn{6}{|c|}{ Visick Grading } & & \\
\hline & & & & \multicolumn{2}{|c|}{1} & \multicolumn{2}{|c|}{2} & \multicolumn{2}{|c|}{$\begin{array}{l}\text { Total } \\
1 \& 2\end{array}$} & \multicolumn{2}{|c|}{3} & \multicolumn{2}{|c|}{4} \\
\hline & & & & No. & $\%$ & No. & $\%$ & No. & $\%$ & No. & $\%$ & No. & $\%$ \\
\hline $\begin{array}{l}\text { Gastrectomy } \\
\text { Vagotomy }\end{array}$ & .. & $\because$. & 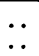 & $\begin{array}{l}13 \\
12\end{array}$ & $\begin{array}{l}26 \\
24\end{array}$ & $\begin{array}{l}26 \\
22\end{array}$ & $\begin{array}{l}52 \\
44\end{array}$ & $\begin{array}{l}39 \\
34\end{array}$ & $\begin{array}{l}78 \\
68\end{array}$ & $\begin{array}{l}7 \\
6\end{array}$ & $\begin{array}{l}14 \\
12\end{array}$ & $\begin{array}{r}4 \\
10\end{array}$ & $\begin{array}{r}8 \\
20\end{array}$ \\
\hline
\end{tabular}

Visick grading: 1 and $2=$ good. $3=$ fair. $4=$ poor.

Differences not significant.

TABLE IV-Numbers of Poor Results in Both Groups

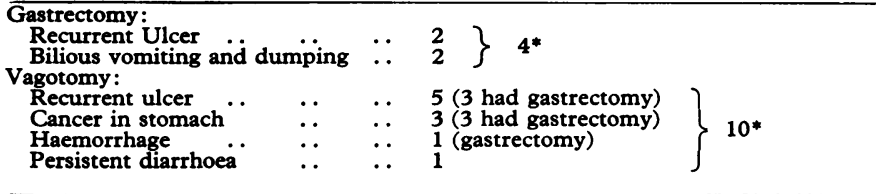

$* \chi^{2}=2.99, P<0.1$; difference is not significant.

required reoperation after vagotomy-seven as against none after gastrectomy $\left(x^{2}=6.65, P<0.01\right)$. The results at the present follow-up, which is an average of about five years, show a slight difference in emphasis from those obtained at an average follow-up of three years. The superiority of Billroth I gastrectomy has not been maintained (table V). This is in part due to an improvement in diarrhoea and postcibal symptoms after vagotomy and in part to more prominence of dumping symptoms after gastrectomy. The overall incidence of postprandial symptoms is now similar in both groups (table VI) with more obvious dumping after gastrectomy and a greater incidence of episodic diarrhoea after vagotomy.

TABLE v-Change in Percentage Functional Results From Three- to Five-year Follow-up

\begin{tabular}{|c|c|c|c|c|c|c|}
\hline & & & & Good & Fair & Poor \\
\hline $\begin{array}{l}\text { Gastrectomy: } \\
\text { Three years ... } \\
\text { Five years } \ldots\end{array}$ & $\because$ & $\because$ & $\therefore$ & $\begin{array}{l}88 \\
78\end{array}$ & $\begin{array}{r}7 \\
14\end{array}$ & $\begin{array}{l}5 \\
8\end{array}$ \\
\hline $\begin{array}{l}\text { Vagotomy: } \\
\text { Three years .. } \\
\text { Five years .. }\end{array}$ & $\because$. & $\ldots$ & $\therefore$ & $\begin{array}{l}60 \\
68\end{array}$ & $\begin{array}{l}20 \\
12\end{array}$ & $\begin{array}{l}20 \\
20\end{array}$ \\
\hline
\end{tabular}

TABLE VI-Incidence of Postprandial Symptoms in Both Groups

\begin{tabular}{|c|c|c|c|c|c|c|}
\hline \multirow{2}{*}{$\begin{array}{l}\text { Percentage } \\
\text { Incidence* }\end{array}$} & \multicolumn{3}{|c|}{ Gastrectomy } & \multicolumn{3}{|c|}{ Vagotomy } \\
\hline & Mild & Moderate & Severe & Mild & Moderate & Severe \\
\hline $\begin{array}{l}\text { Episodic diarrhoea } \\
\text { Bilious vomiting } \\
\text { Early dumping } \quad \ldots \\
\text { Late dumping } \quad . \\
\end{array}$ & $\begin{array}{r}12 \\
8 \\
20 \\
8 \\
\end{array}$ & $\begin{array}{l}\frac{8}{8} \\
4 \\
\end{array}$ & $\begin{array}{r}2 \\
2 \\
4 \\
-\end{array}$ & $\begin{array}{l}\frac{30}{10} \\
10\end{array}$ & $\begin{array}{r}\frac{8}{10} \\
2\end{array}$ & $\underline{z}$ \\
\hline Total & 48 & 20 & 8 & 50 & 20 & 2 \\
\hline
\end{tabular}

*One patient may have more than one symptom.

\section{HAEMATOLOGICAI FINDINGS}

It might be expected that about five years after gastrectomy patients would begin to show some evidence of anaemia and other haematological changes. The only statistically significant difference shown to date is a lower level of serum iron in the patients after gastrectomy (table VII).

TABLE VII-Haematological Data in Both Groups. Values are Mean \pm S.E. of Mean

\begin{tabular}{|c|c|c|c|c|}
\hline & $\begin{array}{l}\text { No. of } \\
\text { Patients }\end{array}$ & Gastrectomy & $\begin{array}{l}\text { No. of } \\
\text { Patients }\end{array}$ & Vagotomy \\
\hline $\begin{array}{l}\text { Haemoglobin }(\%) \\
\text { Serum iron }(\mu \mathrm{g} / \mathrm{ml}) \\
\text { Serum vitamin } \mathrm{B}_{12}(\mathrm{pg} / \mathrm{ml}) \\
\text { Serum folate }(\mathrm{mg} / \mathrm{ml})\end{array}$ & $\begin{array}{l}46 \\
44 \\
43 \\
43\end{array}$ & $\begin{aligned} 97 \cdot 6 & \pm 0 \cdot 6 \\
82 \cdot 1 & \pm 6 \cdot 1 * \\
334 \cdot 0 & \pm 22 \cdot 8 \\
7 \cdot 4 & \pm 0.5\end{aligned}$ & $\begin{array}{l}40 \\
40 \\
40 \\
40\end{array}$ & $\begin{aligned} 98.9 & \pm 0.7 \\
106.6 & \pm 7.2 * \\
349.9 & \pm 21.5 \\
6.7 & \pm 0.6\end{aligned}$ \\
\hline
\end{tabular}

*Significant difference, $\mathrm{P}<0.02$. 
CANCER

The three patients who developed cancer in the stomach after vagotomy and pyloroplasty all had negative biopsies at their initial operation. The time interval between the vagotomy operation for benign gastric ulcer and the appearance of gastric cancer was two years, five years, and six years respectively. The cancers were all poorly differentiated adenocarcinomas with extension into the lymph nodes. These three patients died within 18 months of gastrectomy for carcinoma.

The seven cases who were found to have a carcinoma at the time of intraoperative biopsy and were designated ulcer/cancer were all treated by gastrectomy. Three of these have died, two and a half, three, and four years after operation. The remaining four are alive at the time of writing without evidence of recurrence. With the increasing use of endoscopic biopsy giving more accurate preoperative diagnosis no case of ulcer/cancer has been discovered at operation since 1968.

\section{RECURRENT ULCERATION}

The diagnosis of recurrent ulceration has been confirmed by endoscopy in all cases. Of the two patients with recurrent gastric ulcer after gastrectomy one has been treated with prednisolone for chronic rheumatoid arthritis and both have moderate symptoms which are controlled by medical treatment. In three of the five patients with recurrent ulcer after vagotomy symptoms were severe enough to warrant gastrectomy: the remaining two patients have moderate symptoms and one of them is also having steroid treatment for rheumatoid arthritis. Only one of the patients with recurrent ulcer after vagotomy had a positive gastric response to insulin; none had evidence of delayed gastric emptying.

\section{Discussion}

The relative importance of operative techniques in gastric surgery has altered with the passage of time and this present controlled comparison between gastrectomy and vagotomy for gastric ulcer of the body of the stomach is no exception. Our initial impression that Billroth I gastrectomy gave better functional results (Duthie et al., 1970) has not been substantiated. No statistically significant difference now exists between the Visick grading of the two procedures though more poor results are found in the vagotomy group and seven patients have been submitted to a gastrectomy (three for recurrent gastric ulcer, three for gastric carcinoma, and one for haemorrhage). These further operations tend to be counterbalanced after gastrectomy by the increased immediate postoperative morbidity, the longer stay in hospital, and the lower serum iron as an index of possible developing anaemia. However, it is difficult to remain objective in the face of the significantly greater need for reoperation after vagotomy.

In the cases with late occurrence of gastric cancer histological evidence was obtained at operation of the benign nature of the gastric ulcer and the cancers are thought to be new developments, possibly on the basis of chronic gastritis. It may be that we are not justified in leaving such a large area of stomach liable to gastritis, though cancer can appear in the remnant after partial gastrectomy as well as after drainage procedures (Pack and Banner, 1958). Since the difference in incidence of cancer between the two operative groups is not statistically significant we cannot place emphasis on it unless a longer follow-up reveals more cases.

The incidence of recurrent gastric ulcer (10\%) after vagotomy remains within the range of 0 to $36 \%$ reported in the literature (Weinberg, 1961; Hendry and Bahrani, 1965; Burge, 1966; Dorton, 1966; Farris and Smith, 1966; Kraft et al., 1966; Read, 1966; Stemmer et al., 1968; McNeill et al., 1969; Duthie et al., 1970) even though we have taken care to exclude combined ulcers which do better after vagotomy and pyloroplasty (Douglas and Duthie, 1971). In one case recurrence could be attributed to incomplete vagotomy but in the remainder it can only be suggested that the vagotomy and pyloroplasty had not produced a sufficient alteration in the aetiological factors to maintain healing. With the increasing emphasis on reflux of bile as a contributory cause it is not surprising that some patients with a pyloroplasty should have recurrent ulcer.

This series has given no indication of superiority of conservative surgery for gastric ulcer but it might be possible to improve the results by altering the technique. It is claimed that excision of the ulcer leads to less recurrent ulceration (Daniels and Strachan, 1973). In addition, the maintenance of an intact pylorus should not increase bile reflux. By leaving the vagal nerve supply to the antral region of the stomach and denervating the remainder (highly selective vagotomy, proximal gastric vagotomy) a pyloroplasty can be avoided (Johnston and Wilkinson, 1970). Initial results suggest that dumping and diarrhoea may be less after highly selective vagotomy. In view of our own encouraging preliminary results we have now embarked on a controlled comparison between Billroth I gastrectomy and the procedure of excision of the ulcer combined with highly selective vagotomy without pyloroplasty. In the first 20 cases both groups are satisfactory, but only long follow-up will establish any real advantage of either procedure.

It seems reasonable to use conservative surgery as an alternative to partial gastrectomy for gastric ulcer of the body of the stomach, especially if the latter would be technically more difficult, but the ulcer must be biopsied if it is to be left behind. No evidence has been presented to support the abandoning of Billroth I partial gastrectomy in the treatment of gastric ulcer.

\section{References}

Burge, H. (1966). Annals of the Royal College of Surgeons of England, 38, 349. Daniels, H. A., and Strachan, A. W. B. (1973). British fournal of Surgery,

60, 389.
Dorton, H. E. (1966). Surgery, Gynecology and Obstetrics, 122, 1015.

Dorton, H. E. (1966). Surgery, Gynecology and Obstetrics, 122, 1015.

Douglas, M. C., and Duthie, H. L. (1971). British fournal of Surgery, 58, 721. British fournal of Surgery, 57, 784.

Farris, J. M., and Smith, G. K. (1966). Surgical Clinics of North America, 46, 329.

Hendry, W. G., and Bahrani, S. Al (1965). British fournal of Surgery, 52. 588 Johnston, D., and Wilkinson, A. R. (1970). British fournal of Surgery 57, 289.

Kraft, R. O., Fry, W. J., and Ransom, H. K. (1966). Archives of Surgery, 92,456

McNeill, A. D., McAdam, W. A. F., and Hutchison, J. S. F. (1969). Surgery, Gynecology and Obstetrics, 128, 91 .

Pack, G. T., and Banner, R. L. (1958). Surgery, 44, 1024

Read, R. C.' (1966). Archives of Surgery, 92, 461.

Stemmer, E. A., Zahn, R. L., Hom, L. W., and Connolly, J. F. (1968). Archives of Surgery, 96, 586.

Weinberg, J. A. (1961). In Surgery of Stomach and Duodenum, ed. H. N. Harkins and L. M. Nyhus. Boston, Little Brown. 